\title{
Effects of silicon and drought stress on biochemical characteristics of leaves of upland rice cultivars ${ }^{1}$
}

\author{
Características bioquímicas nas folhas de cultivares de arroz de terras altas em função \\ de silício e estresse hídrico
}

\author{
Munir Mauad², Carlos Alexandre Costa Crusciol ${ }^{3}$, Adriano Stephan Nascente $^{4 *}$, Hélio Grassi Filho ${ }^{5}$ and \\ Giuseppina Pace Pereira Lima
}

\begin{abstract}
Silicon ( $\mathrm{Si}$ ) has beneficial effects on many crops, mainly under biotic and abiotic stress. Silicon can affect biochemical, physiological, and photosynthetic processes and, consequently, reduce drought stress. However, the effects of Si on rice (Oryza sativa L.) plants under drought stress are not well known. The objective of this study was to evaluate the effects of supplemental Si on proline content and peroxidase activity in upland rice plants in the presence and absence of drought stress. The experiment was conducted under greenhouse conditions and was arranged in completely randomized blocks in a $2 \times 2 \times 2$ factorial scheme. Treatments comprised combinations of (1) presence or absence of Si supply ( 0 or $350 \mathrm{~kg} \mathrm{ha}^{-1}$ of $\left.\mathrm{Si}\right)$, (2) presence or absence of a water deficit $(-0.050 \mathrm{MPa}$ or $-0.025 \mathrm{MPa}$ soil water potential values, respectively), and (3) two upland rice cultivars: Caiapo (traditional type) and Maravilha (modern type), with eight replications. Under water stress conditions, silicon fertilization reduced the proline content in the vegetative and reproductive phases of upland rice plants and increased peroxidase activity in the plants' reproductive phase, which could be indicative of stress tolerance.
\end{abstract}

Key words: Oryza sativa. Proline. Peroxidase. Enzyme. Hydric deficiency.

RESUMO - O silício tem efeitos benéficos sobre diversas culturas, principalmente sob estresses bióticos e abióticos. O silício pode afetar processos bioquímicos, fisiológicos e fotossintéticos e, conseqüentemente aliviar o estresse hídrico. No entanto, os efeitos do Si sobre plantas arroz (Oryza sativa L.) sob estresse hídrico não são muito bem conhecidos. O objetivo deste estudo foi avaliar o efeito do suprimento de Si no teor de prolina e na atividade da peroxidase em plantas de arroz de terras altas, expostos ou não ao estresse hídrico. O experimento foi realizado em casa de vegetação arranjados em um delineamento em blocos completos casualisados em esquema fatorial $2 \times 2 \times 2$. Os tratamentos consistiram na ausência ou na presença de Si (0 e $\left.350 \mathrm{~kg} \mathrm{ha}^{-1}\right)$ com a ausência ou presença de déficit hídrico (- 0,025 MPa e - 0,050 MPa potencial de água no solo, respectivamente) e duas cultivares de arroz Caiapo (tipo tradicional) e Maravilha (tipo moderno), com oito repetições. Sob condições de estresse hídrico, a adubação com silício reduz o teor de prolina nas fases vegetativa e reprodutiva das plantas de arroz de terras altas e a atividade da peroxidase aumenta na fase reprodutiva do arroz, o que pode ser indicativo de tolerância ao stress.

Palavras-chave: Oryza sativa. Prolina. Peroxidase. Enzima. Deficiência hídrica.

\footnotetext{
*Autor para correspondência

DOI: $10.5935 / 1806-6690.20160064$

${ }^{1}$ Recebido para publicação em 12/08/2013; aprovado em 06/10/2015

Parte da Tese de Doutorado do primeiro autor apresentada à Universidade Estadual Paulista Julio de Mesquita Filho/UNESP

${ }^{2}$ Faculdade de Ciências Agrárias, Universidade Federal da Grande Dourados, Dourados-MS, Brasil, 79.804-970, munirmauad@ufgd.edu.br

${ }^{3}$ Departamento de Produção Vegetal, Faculdade Ciências Agronômicas, Fazenda Lageado, Universidade Estadual Paulista "Júlio de Mesquita Filho"/UNESP, Campus Botucatu, Botucatu-SP, Brasil, 18.603-970, crusciol@ fca.unesp.br

${ }^{4}$ Embrapa Arroz e Feijão, Rodovia GO-462, km 12 Rural, Caixa Postal 179, Santo Antônio de Goiás-GO, Brasil, 75.375-000, adriano.nascente@ embrapa.br

${ }^{5}$ Departamento de Solos e Recursos Ambientais, Faculdade de Ciências Agronômicas, Fazenda Lageado, Universidade Estadual Paulista "Júlio de Mesquita Filho"/UNESP, Campus Botucatu, Botucatu-SP, Brasil, 18.610-307, heliograssi@fca.unesp.br

${ }^{6}$ Departamento de Química, Instituto de Biociências, Universidade Estadual Paulista "Júlio de Mesquita Filho"/UNESP, Campus Botucatu, Botucatu-SP, Brasil, 18.610-307, giuseppina@fca.unesp.br
} 


\section{INTRODUCTION}

Upland rice cultivation is increasing in importance worldwide as the water available for rice irrigation decreases, and is especially important in China due to urban and industrial growth (QU et al., 2008; NASCENTE et al., 2013). Therefore, a better understanding of the biochemical mechanisms of drought resistance will help to improve and stabilize rice yield under upland conditions and provide additional water savings (CARLIN; SANTOS, 2009).

Plant tolerance to unfavorable conditions, particularly water deficit, has been associated with proline (a non-protein amino acid formed in the leaf tissues of plants exposed to water stress) accumulation and increased antioxidative enzymes such as peroxidase (ASHRAF; FOOLAD, 2007). This enzyme is involved in many reactions inside plants, such as linking polysaccharides, oxidation of indole-3-acetic acid, monomer connections, lignification, oxidation of phenols, pathogen defense, regulation of cell elongation and others (KAO, 2003). Therefore, peroxidase may represent a regulatory mechanism for water loss by reducing cell water potential (CARLIN; SANTOS, 2009; CRUSCIOL et al., 2009; FUMIS; PEDRAS, 2002; SHARMA; DUBEY, 2005). It may also be a biochemical marker of metabolic alterations generated by different types of stress, as reported by many authors (LIMA et al., 2004; RAYMOND; SMIRNOFF, 2002; SHARMA; DUBEY, 2005).

However, the levels of proline in rice plants under stress are not well studied (CARLIN; SANTOS, 2009; DINGKUHN et al., 1991; FUMIS; PEDRAS, 2002; LIMA et al., 2004). Therefore, it is important to evaluate the behavior of new cultivars of upland rice under hydric deficiency (HEINEMANN; STONE; FAGERA, 2011).

Silicon is the second most abundant element in the Earth's crust (MA et al., 2006), and several studies have demonstrated that $\mathrm{Si}$ plays an important role in plant tolerance to environmental stresses (GONG et al., 2005; GUNES et al., 2007a,b, 2008; MA, 2004; ZHU et al., 2004;). In this sense, Gao et al. (2004), Gong et al. (2005), Gunes et al. (2007a) and Zhu et al. (2004) verified that application of Si induced higher proline concentrations under conditions of water deficit. According to the abovementioned authors, the effect of $\mathrm{Si}$ on the greater tolerance of higher plants to drought could be associated with an increase in the action of antioxidant defenses, a reduction in the oxidative damage to functional molecules and membranes, and maintenance of many physiological as well as photosynthetic processes under water deficit conditions. MING et al. (2012) stated that silicon application could enhance the resistance of upland rice roots to water deficit stress by preventing the rapid decline of physiological and biochemical activities in roots.

Drought stress has been found to increase stomatal resistance, leaf hydrogen peroxide and proline concentrations, and leaf lipid peroxidation in chickpea (Cicer arietinum L.) (GUNES et al., 2007b), sunflower (Helianthus annuus L.) (GUNES et al., 2008) and rice (CHANDRU et al., 2003). However, Si application decreased the levels of the above factors and alleviated membrane damage significantly by increasing leaf relative water content. Silicon fertilization reduced proline levels, indicating that $\mathrm{Si}$ reduces stress levels because proline is considered a biochemical indicator of stress and an osmotic regulator (GUNES et al., 2008). Silicon is also known as an anti-stress agent and can reduce cuticle transpiration (MA et al., 2006) or increase water efficiency (GAO et al., 2004).

In this regard, there is not much information in the literature indicating whether $\mathrm{Si}$ application may have similar beneficial effects on rice under drought stress. This information will help scientists choose genotypes that are more tolerant to hydric deficiency for breeding (HEINEMANN; STONE; FAGERA, 2011). The reported work aimed to evaluate the effects of $\mathrm{Si}$ supply on leaf concentrations of $\mathrm{Si}$, proline content and peroxidase activity in upland rice cultivars grown either with or without exposure to soil water deficits.

\section{MATERIAL AND METHODS}

The experiment was performed under greenhouse conditions in Botucatu, São Paulo, Brazil, in 40-L pots $(0.40 \times 0.40 \times 0.25 \mathrm{~m})$ with an effective depth of 0.30 $\mathrm{m}$ and a hole at the bottom to drain excess water. Pots contained $40 \mathrm{dm}^{3}$ of a Typic Acrortox soil (33\% clay, 4\% silt, and $63 \%$ sand). The soil had the following properties: $\mathrm{pH}\left(1: 2.5\right.$ soil/ $\mathrm{CaCl}_{2}$ suspension, $\left.0.01 \mathrm{~mol} \mathrm{~L}^{-1}\right) 4.0,8 \mathrm{~g}$ $\mathrm{dm}^{-3}$ organic matter, $3.0 \mathrm{mg} \mathrm{dm}^{-3} \mathrm{P}, 11.0 \mathrm{mmol}_{\mathrm{c}} \mathrm{dm}^{-3} \mathrm{Ca}$, $2.0 \mathrm{mmol}_{\mathrm{c}} \mathrm{dm}^{-3} \mathrm{Mg}, 0.6 \mathrm{mmol}_{\mathrm{c}} \mathrm{dm}^{-3} \mathrm{~K}, 72.0 \mathrm{mmol}_{\mathrm{c}} \mathrm{dm}^{-3}$ $\mathrm{H}+\mathrm{Al}$, and $16.0 \%$ base saturation. All of the soil chemical attributes were analyzed according to van Raij et al. (2001).

The experiment was arranged in completely randomized blocks in a $2 \times 2 \times 2$ factorial scheme. Treatments comprised combinations between the presence or absence of supplied Si $\left(0\right.$ or $350 \mathrm{~kg} \mathrm{ha}^{-1}$ of $\mathrm{Si}$ ) and the presence or absence of a water deficit $(-0.050 \mathrm{MPa}$ or $-0.025 \mathrm{MPa}$ soil water potential values) applied to two upland rice cultivars: Caiapo (traditional type) and Maravilha (modern type). 
Each pot was considered an experimental unit. Eight replicates of each combination were set up, totaling 64 experimental units $(2 \times 2 \times 2=8 \times 8=64)$.

In order to establish the $\mathrm{Si}$ treatments, base saturation was increased to $60 \%$ by applying $\mathrm{Ca}$ and $\mathrm{Mg}$ silicate to 32 pots, while the other 32 pots received an application of dolomitic lime. Materials for correcting $\mathrm{pH}$ that had particles smaller than $0.30 \mathrm{~mm}$ (50 mesh) were used to enable the full soil reaction during the incubation period. Moreover, $150 \mathrm{mg} \mathrm{dm}^{-3} \mathrm{P}$ (single superphosphate, $18 \% \mathrm{P}_{2} \mathrm{O}_{5}$ ), $150 \mathrm{mg} \mathrm{dm}^{-3} \mathrm{~K}$ (potassium chloride, $60 \% \mathrm{~K}_{2} \mathrm{O}$ ), $5 \mathrm{mg} \mathrm{dm}^{-3} \mathrm{Zn}$, and $1 \mathrm{mg} \mathrm{dm}^{-3} \mathrm{~B}$ (fritted trace elements BR12, 9\% $\mathrm{Zn}$ and $1.8 \% \mathrm{~B}$ ) were added. The soil was then wetted to field capacity, covered with polyethylene film, and incubated for $30 \mathrm{~d}$ at $25^{\circ} \mathrm{C}$. Silicon was incorporated into the soil 2 days before sowing rice.

The rice was sown using 50 seeds in a $0.40 \mathrm{~m}$ row in each pot. Emergence occurred $5 \mathrm{~d}$ after sowing. At $9 \mathrm{~d}$ after emergence (DAE) mowing was done, leaving 30 plants per pot. Nitrogen and $\mathrm{K}$ were supplied (30 DAE) at concentrations of $30 \mathrm{mg} \mathrm{dm}^{-3} \mathrm{~N}$ (as urea) and $30 \mathrm{mg} \mathrm{dm}^{-3}$ $\mathrm{K}$ (as potassium chloride).

Soil water potential was monitored with conventional mercury tensiometers $(13-\mathrm{mm}$ in diameter, with a ceramic porous cup connected with tubing to a mercury manometer), which were constructed according to Richards (1949), and installed on the sowing date at a $15 \mathrm{~cm}$ depth, in four replications of each treatment (32 pots). After plant emergence and before the water deficit treatments were established, water additions were performed when the mean water potential in the soil reached $-0.025 \mathrm{MPa}$. The treatments with soil water potentials of -0.025 and -0.050 MPa were established at 17 DAE and maintained until 70 DAE. Required water additions were performed according to recommendations by Crusciol et al. (2006) and the soil's water retention capacity curve. The soil's water retention capacity curve was determined in the laboratory according to the pressure plate methodology recommended by Richards (1949). The total water applied was 323 and $392 \mathrm{~mm}$, respectively, in the treatments with and without water deficit.

When plants were at 40 DAE (vegetative stage) and 70 DAE (reproductive stage), four fresh leaves per pot (the first completely expanded leaves counting from the plant apex) were collected and immediately frozen in liquid nitrogen for use in biochemical determinations. The method of Torello and Rice (1986) was used for proline determination. Therefore, samples of plant tissue weighing $0.3 \mathrm{~g}$ were wetted and homogenized in $10 \mathrm{~mL}$ of a solution of sulfosalicilic acid (3\%) in polyethylene tubes followed by centrifugation at $5000 \mathrm{rpm}$ for 20 minutes. Afterward, one 2-ml aliquot of the supernatant was set aside and $2 \mathrm{ml}$ of ninhidrina acid (BATES, WALDREN;
TEARE, 1973) and $2 \mathrm{ml}$ of acetic acid were added. Then, the samples were placed in water to boil for 1 hour, after which they were cooled with ice cubes. Data was then collected on a spectrophotometer at a wavelength of $520 \mathrm{~nm}$. Data are shown as micromoles of proline per $\mathrm{g}$ of fresh material.

To determine peroxidase enzyme activity, samples of fresh plant tissue weighing $0.3 \mathrm{~g}$ were wetted and homogenized in a $0.2 \mathrm{M}$ phosphate solution at pH 6.7 and centrifuged at 10,000 rpm for 10 minutes. Peroxidase activity in the supernatant was determined by measuring the absorbance at $470 \mathrm{~nm}$ of tetraguaiacol (MACIEL et al., 2007). The specific activity of peroxidase is shown as milligrams of protein per gram of fresh tissue.

Data were subjected to analysis of variance, and means were separated using the LSD test at the 0.05 probability level.

\section{RESULTS AND DISCUSSIONS}

Proline concentrations in the leaves were affected by the choice of cultivar, drought, $\mathrm{Si}$, and the interaction of drought $\times \mathrm{Si}$ and drought $\mathrm{x}$ cultivar $\mathrm{x}$ Si (Table 1).

Under water stress, both of the rice cultivars tested produced higher concentrations of proline in their leaves (Table 2). Proline is an amino acid synthetized under stress conditions (CRUSCIOL et al., 2009). According to Crusciol et al. (2006) the ideal water tension for a rice cultivar is $-0.025 \mathrm{MPa}$, and when this tension is increased due to hydric deficiency, a reduction in rice yield results. Therefore, increasing the soil water tension produced stress in the rice plants and consequently induced them to produce proline.

Some authors suggest that proline is an indicator of water stress (BECKER; FOCK, 1986; CARLIN; SANTOS, 2009; CRUSCIOL et al., 2009). In this regard, under low water tension $(-0.025 \mathrm{MPa})$, the levels of proline were low also (Table 2). The data obtained in the present paper may indicate that, under water deficit conditions, the level of proline in rice leaves increases. Increased proline levels as a function of hydric deficiency have also been observed in rice (DINGKUHN et al., 1991, LIMA et al., 2004) and wheat (FUMIS; PEDRAS, 2002).

Upon analysis of the interaction cultivar $\mathrm{x}$ water tension, an effect was observed only for $-0.050 \mathrm{MPa}$, in which the Caiapo cultivar showed the highest proline activity (Table 2). Caiapo is a traditional cultivar recommended for cultivation in upland areas due to its greater tolerance to drought, while Maravilha is suitable for cultivation under irrigation (CRUSCIOL et al., 2006). 
Therefore, we could infer that the content of proline in the cultivar Caiapo indicates greater drought tolerance.

Analysis of the interaction Si $\mathrm{x}$ water deficiency (Table 2) revealed that a water tension of $-0.050 \mathrm{MPa}$ was distinct from $-0.025 \mathrm{MPa}$ at both doses of silicon. These results are similar to those obtained by many authors (CARLIN; SANTOS, 2009; CRUSCIOL et al., 2009; DINGKUHN et al., 1991; GUNES et al., 2007b; GUNES et al., 2008; LIMA et al., 2004), where increasing water stress was seen to increase the levels of proline in plants. For silicon application, the effect was observed only at $0.0050 \mathrm{MPa}$.

Silicon fertilization may have reduced water loss by the rice plants, so proline levels were lower in this situation (Table 2), because proline is described as an osmotic regulator (GUNES et al., 2008). Under conditions ideal for upland rice development, $-0.025 \mathrm{MPa}$ (CRUSCIOL et al., 2006), no significant effect of silicon fertilization on proline levels was observed, which may indicate that silicon fertilization is more effective under stress conditions (MA, 2004). Si application could reduce levels of proline and, therefore, stress levels, given that proline is a biochemical indicator of stress (GUNES et al., 2008).

When the effects of water stress x cultivar on levels of proline (Table 2) were analyzed, an effect was observed only for Maravilha at $-0.050 \mathrm{MPa}$, where levels of proline were increased. Differences in proline levels as a function of cultivar were also observed by Dingkuhn et al. (1991) and Lima et al. (2004) in rice. This may be an intrinsic characteristic of each cultivar. For silicon fertilization $\mathrm{x}$ cultivar, an effect was observed only in Maravilha at 0 Si (Table 2), where no silicon fertilization promoted an increase in proline levels in the reproductive phase. Maravilha has less tolerance to water stress than Caiapo (CRUSCIOL et al., 2006). In the interaction between water tension and silicon, proline levels were increased only for the condition of no silicon and higher stress (-0.050 MPa). This indicates that silicon reduced the levels of stress in the plants and, consequently, the levels of proline, as

Table 1 - Levels of proline in the leaves of rice plants in the vegetative and reproductive phases as a function of water tension, silicon fertilization and cultivars

\begin{tabular}{|c|c|c|}
\hline \multirow{2}{*}{ Treatments } & \multicolumn{2}{|c|}{ Proline content } \\
\hline & Vegetative phase & Reproductive phase \\
\hline Cultivar & \multicolumn{2}{|c|}{$\mu \mathrm{mol} \mathrm{g}^{-1}$} \\
\hline Caiapo & $2.5357 \mathrm{a}^{(1)}$ & $0.4465 \mathrm{~b}$ \\
\hline Maravilha & $0.7709 \mathrm{~b}$ & $0.6136 \mathrm{a}$ \\
\hline \multicolumn{3}{|c|}{ Water tension $(\mathrm{MPa})$} \\
\hline-0.025 & $0.32871 \mathrm{~b}$ & $0.4022 \mathrm{~b}$ \\
\hline-0.050 & $2.9789 \mathrm{a}$ & $0.6579 \mathrm{a}$ \\
\hline \multicolumn{3}{|c|}{ Silicon fertilization $\left(\mathrm{kg} \mathrm{ha}^{-1}\right)$} \\
\hline 0 & $1.8048 \mathrm{a}$ & $0.6830 \mathrm{a}$ \\
\hline 350 & $1.5019 \mathrm{~b}$ & $0.3771 \mathrm{~b}$ \\
\hline Factor & \multicolumn{2}{|c|}{ F values $^{(2)}$} \\
\hline Blocks & $0.31^{\mathrm{ns}}$ & $0.48^{\mathrm{ns}}$ \\
\hline Cultivar (C) & $245.29 * *$ & $7.04 *$ \\
\hline Water tension (WT) & $552.80 * *$ & $16.58 * *$ \\
\hline Silicon (S) & $7.22 *$ & $23.73 * *$ \\
\hline $\mathrm{C} \times \mathrm{WT}$ & $233.46^{* *}$ & $10.45 * *$ \\
\hline $\mathrm{C} \times \mathrm{S}$ & $2.11^{\mathrm{ns}}$ & $4.74 *$ \\
\hline WT x S & $8.50 *$ & $13.72 *$ \\
\hline Cx WT x S & $0.064^{\mathrm{ns}}$ & $7.92^{\mathrm{ns}}$ \\
\hline $\mathrm{CV}(\%)$ & 19.28 & 33.51 \\
\hline
\end{tabular}

(1) Means followed by the same letter don't differ significantly by the LSD test at $\mathrm{p}<0.05 .{ }^{(2)} * *, *$ and ns indicate: significant at $1 \%$ and $5 \%$, and not significant, respectively 
Table 2 - Significant interactions according to analysis of variance regarding proline activity ( $\mu \mathrm{mol} \mathrm{g}^{-1}$ ) in the vegetative and reproductive phases

\begin{tabular}{|c|c|c|}
\hline \multicolumn{3}{|c|}{ Interaction in vegetative phase } \\
\hline \multirow{3}{*}{ Cultivar } & \multicolumn{2}{|c|}{ Soil water tension } \\
\hline & $-0.025 \mathrm{MPa}$ & $-0.050 \mathrm{MPa}$ \\
\hline & \multicolumn{2}{|c|}{$\left(\mu \mathrm{mol} \mathrm{g}{ }^{-1}\right)$} \\
\hline Caiapo & $0.3502 \mathrm{a}^{(1)} \mathrm{B}$ & 4.7212 a A \\
\hline Maravilha & 0.3071 a B & $1.2347 \mathrm{~b} \mathrm{~A}$ \\
\hline \multicolumn{3}{|c|}{ Silicon fertilization $\left(\mathrm{kg} \mathrm{ha}^{-1}\right)$} \\
\hline 0 & 0.3158 a B & 3.2937 a A \\
\hline 350 & $0.3415 \mathrm{a} \mathrm{B}$ & $2.662 \mathrm{~b} \mathrm{~A}$ \\
\hline \multicolumn{3}{|c|}{ Interaction in reproductive phase } \\
\hline \multicolumn{3}{|l|}{ Cultivar } \\
\hline Caiapo & 0.4202 a A & 0.4729 a A \\
\hline Maravilha & $0.04205 \mathrm{a} \mathrm{B}$ & $0.8434 \mathrm{~b} \mathrm{~A}$ \\
\hline \multirow{2}{*}{ Cultivar } & \multicolumn{2}{|c|}{ Silicon fertilization } \\
\hline & $0 \mathrm{~kg} \mathrm{ha}^{-1}$ & $350 \mathrm{~kg} \mathrm{ha}^{-1}$ \\
\hline Caiapo & $0.5311 \mathrm{a} \mathrm{A}$ & 0.3620 a A \\
\hline Maravilha & $0.8349 \mathrm{~b} \mathrm{~A}$ & 0.3923 a B \\
\hline Silicon fertilization & \multicolumn{2}{|c|}{ Soil water tension } \\
\hline$\left(\mathrm{Kg} \mathrm{ha}^{-1}\right)$ & $-0.025 \mathrm{MPa}$ & $-0.050 \mathrm{Mpa}$ \\
\hline 0 & 0.4388 a B & 0.9272 a A \\
\hline 350 & 0.3656 a A & $0.3886 \mathrm{~b} \mathrm{~A}$ \\
\hline
\end{tabular}

${ }^{1}$ Means followed by the same letter (uppercase horizontally and lowercase vertically) don't differ by the LSD test at $\mathrm{p}<0.05$

observed by many authors (CARLIN; SANTOS, 2009; CRUSCIOL et al., 2009). On the other hand, Gong et al. (2005) observed that application of Si reduced proline levels, as observed in this trial.

A notable difference in the data for peroxidase was that the cultivar Maravilha had higher peroxidase activity than the cultivar Caiapo (Table 3). In this context, water stress is also known to cause oxidative damage to plants, leading to increased production of reactive oxygen species (HEINEMANN; STONE; FAGERA, 2011; VERMA; DUBEY, 2003). Thus, the higher peroxidase activity in Maravilha is related to the genetic characteristics of the plant. However, it is noteworthy that this material has a low resistance to water deficit, which may lead to an increase in peroxidase as a protection against this type of stress. An effect of cultivar and the interaction water tension $\mathrm{x}$ Si was observed in the vegetative phase (Table 3 ). In addition, there were effects produced by the interactions cultivar $\mathrm{x} \mathrm{Si}$ and water tension $\mathrm{x} \mathrm{Si}$ in the reproductive phase.
Therefore, for the interaction water stress $\mathrm{x}$ silicon, there was an effect only at the zero dose, where a water tension of $-0.050 \mathrm{MPa}$ yielded the highest peroxidase activity (Table 4). One form of plant defense is to activate antioxidant enzymes, such as peroxidase, to defend against the deleterious effects of oxidative metabolism (LIMA et al., 2004). It was observed that, when silicon was provided, there was no significant difference in peroxidase activity in the vegetative phase (Table 4). However, a slight tendency to lower activity was observed, which could indicate inhibition of this enzyme in the presence of silicon during this phase.

Increased activity of antioxidant enzymes in rice plants under stress conditions was observed by Verma and Dubey (2003) and Chandru et al. (2003) as a defense mechanism against stress. According to the authors, these enzymes break reactive oxygen species into water and molecular oxygen, preventing lipid peroxidation. In the interaction $\mathrm{Si} \mathrm{x}$ water tension, an effect was noted only at $-0.025 \mathrm{MPa}$, at which silicon fertilization increased peroxidase activity. 
Table 3 - Peroxidase activity in the vegetative and reproductive phases as a function of water tension, silicon fertilization and cultivar choice

\begin{tabular}{|c|c|c|}
\hline \multirow{2}{*}{ Treatments } & \multicolumn{2}{|c|}{ Peroxidase activity } \\
\hline & Vegetative phase & Reproductive phase \\
\hline Cultivar & \multicolumn{2}{|c|}{$\%$} \\
\hline Caiapo & $0.0731 \mathrm{~b}^{(1)}$ & $0.0755 \mathrm{a}$ \\
\hline Maravilha & $0.0979 \mathrm{a}$ & $0.0818 \mathrm{a}$ \\
\hline \multicolumn{3}{|c|}{ Water tension $(\mathrm{MPa})$} \\
\hline-0.025 & $0.0784 \mathrm{a}$ & $0.0634 \mathrm{~b}$ \\
\hline-0.050 & $0.0926 \mathrm{a}$ & $0.0939 \mathrm{a}$ \\
\hline \multicolumn{3}{|c|}{ Silicon fertilization $\left(\mathrm{kg} \mathrm{ha}^{-1}\right)$} \\
\hline 0 & $0.0785 \mathrm{a}$ & $0.0701 \mathrm{~b}$ \\
\hline 350 & $0.0925 \mathrm{a}$ & $0.0872 \mathrm{a}$ \\
\hline Factor & \multicolumn{2}{|c|}{$\mathrm{F}_{\text {values }}^{(2)}$} \\
\hline Blocks & $1.13^{\mathrm{ns}}$ & $2.48^{\mathrm{ns}}$ \\
\hline Cultivar (C) & $5.51 *$ & $1.65^{\mathrm{ns}}$ \\
\hline Water tension (WT) & $1.18^{\mathrm{ns}}$ & $38.24 * *$ \\
\hline Silicon (S) & $1.75^{\mathrm{ns}}$ & $12.12 * *$ \\
\hline $\mathrm{C} \times \mathrm{WT}$ & $0.02^{\mathrm{ns}}$ & $0.38^{\mathrm{ns}}$ \\
\hline $\mathrm{C} \times \mathrm{S}$ & $0.15^{\mathrm{ns}}$ & $28.53 * *$ \\
\hline WT x S & $8.71 * *$ & $33.67 * *$ \\
\hline C x WT x S & $3.45^{\mathrm{ns}}$ & $2.53^{\mathrm{ns}}$ \\
\hline $\mathrm{CV}(\%)$ & 34.84 & 17.70 \\
\hline
\end{tabular}

(1) Means followed by the same letter don't differ significantly by the LSD test at $\mathrm{p}<0.05$. ${ }^{(2) * *}, *$ and ns indicate: significant at $1 \%$ and $5 \%$, and not significant, respectively

Table 4 - Significant interactions affecting peroxidase activity (\%) according to analysis of variance in the vegetative and reproductive phases

\begin{tabular}{|c|c|c|}
\hline \multicolumn{3}{|c|}{ Interaction in vegetative phase } \\
\hline \multirow{2}{*}{ Silicon fertilization } & \multicolumn{2}{|c|}{ Soil water tension } \\
\hline & $-0,025 \mathrm{MPa}$ & $-0.050 \mathrm{Mpa}$ \\
\hline $\mathrm{Kg} \mathrm{ha}^{-1}$ & & \\
\hline 0 & $0.0559 \mathrm{a} \mathrm{B}^{(1)}$ & 0.1011 a A \\
\hline 350 & $0.1010 \mathrm{~b} \mathrm{~A}$ & 0.0840 a A \\
\hline \multicolumn{3}{|c|}{ Interaction in reproductive phase } \\
\hline \multicolumn{3}{|l|}{ Cultivar } \\
\hline Caiapo & 0.0618 a B & $0.0892 \mathrm{~b} \mathrm{~A}$ \\
\hline Maravilha & 0.0650 a B & 0.0986 a A \\
\hline \multicolumn{3}{|c|}{ Silicon fertilization $\mathrm{Kg} \mathrm{ha}^{-1}$} \\
\hline 0 & 0.0691 a A & $0.0710 \mathrm{~b} \mathrm{~A}$ \\
\hline 350 & 0.0577 a B & 0.1167 a A \\
\hline
\end{tabular}

${ }^{(1)}$ Means followed by the same letter (uppercase horizontally and lowercase vertically) don't differ by the LSD test at $\mathrm{p}<0.05$ 
In the reproductive phase, the interaction water stress x cultivar (Table 4) had significant effects in both cultivars, observed as higher peroxidase activity with higher water tension. This increase may be related to the defense mechanism of action of oxidative enzymes. These results corroborate Lima et al. (2004), Verma and Dubey (2003) and Chandru et al. (2003).

When the interaction cultivar $\mathrm{x}$ soil water tension was analyzed, there was an effect at $-0.050 \mathrm{MPa}$ only, at which Maravilha had higher peroxidase activity than the cultivar Caiapo. Maravilha has less drought tolerance than Caiapo. The increased water tension in the soil above the recommended level $(-0.025 \mathrm{MPa})$ creates a condition of water stress, causing the Maravilha cultivar to experience more stress than the Caiapo cultivar. Therefore, the activity of antioxidant enzymes is increased under water deficit conditions, as well as in less drought-tolerant cultivars, as a defense against oxidative metabolism.

In the interaction soil water tension $\mathrm{x} \mathrm{Si}$, there was an effect only at the $350 \mathrm{~kg} \mathrm{ha}^{-1}$ dose of silicon and a tension of $-0.050 \mathrm{MPa}$, in which silicon fertilization increased the activity of peroxidase (Table 4). Several authors have stated that silicon is involved in increased tolerance to biotic and abiotic stress (CRUSCIOL et al., 2009). Thus, under conditions of water stress, plants that were fertilized with silicon showed increased activity of peroxidase, an enzyme related to mechanisms of plant defense. The peroxidase prevents oxidation of lipids (VERMA; DUBEY, 2003). Similarly, the silicon would act on membrane stability, reducing membrane permeability under stress conditions (FAUTEUX et $a l ., 2006)$ and increasing phospholipid and glycolipid contents (WANG; GALLETTA, 1998). This action would contribute to the protective effect on the plant, resulting in increased activity of peroxidases (FAUTEUX et al., 2006). Liang (1999) found a $24 \%$ increase in peroxidase activity in rice plants under stress conditions in the presence of silicon.

\section{CONCLUSION}

Under water stress conditions, silicon fertilization reduces the proline content of upland rice plants in both the vegetative and reproductive phases and increases peroxidase activity in the reproductive phase, which could be indicative of stress tolerance.

\section{REFERENCES}

ASHRAF, M.; FOOLAD, M. R. Roles of glycine betaine and proline in improving plant abiotic stress resistance.
Environmental and Experimental Botany, v. 59, n. 2, p. 206216, 2007.

BATES, L. S.; WALDREN, R. P.; TEARE I. D. Rapid determination of free proline for water-stress studies. Plant and Soil, v. 39, n. 2, p. 205-207, 1973.

BECKER, T. W.; FOCK, H. P. The activity of nitrate redutase and poll sizes of some amino acids and some sugars in waterstressed maize leaves. Photosynthesis Research, v. 8, n. 3, p. 267-274, 1986.

CARLIN, S. D.; SANTOS, D. M. M. Physiological indicators of the interaction between water deficit and soil acidity in sugarcane. Pesquisa Agropecuaria Brasileira, v. 44, n. 9, p. 1106-1113, 2009.

CHANDRU, H. K. et al. Kinetics of wound induced activation of antioxidative enzymes in Oryza sativa: differencial activation at different growth stages. Plant Science, v. 164, n. 6, p. 935-941, 2003.

CRUSCIOL, C. A. C. et al. Effects of Silicon and Drought Stress on Tuber Yield and Leaf Biochemical Characteristics in Potato. Crop Science, v. 49, n. 3, p. 949-954, 2009.

CRUSCIOL, C. A. C. et al. Yield of upland rice cultivars in rainfed and sprinkler-irrigated systems in the Cerrado region of Brazil. Australian Journal of Experimental Agriculture, v. 46, n. 11, p. 1515-1520, 2006.

DINGKUHN, M. et al. Responses of seven diverse rice cultivars to water deficits. III: Accumualation of abscisic acid and proline in relation to leaf water-potencial and osmotic adjustament. Field Crops Research, v. 27, n. 1/2, p. 103-117, 1991.

FAUTEUX, F. et al. The protective role of silicon in the Aradidopsis powder mildew pathosystem. Procceding of the National Academy of the United State of America, v. 103, n. 46, p. 17554-17559, 2006.

FUMIS, T. F.; PEDRAS, J. F. Proline, diamine and polyamines accumulation in wheat cultivars submitted to water deficits. Pesquisa Agropecuaria Brasileira, v. 37, n. 4, p. 449-459, 2002.

GAO, X. et al. Silicon improves water use efficiency in Maize plants. Journal of Plant Nutrition, v. 27, n. 8, p. 1457-1470, 2004.

GONG, H. et al. Silicon alleviates oxidative damage of wheat plants in pots under drought. Plant Science, v. 169, n. 13-14, p. 313-321, 2005.

GUNES, A. et al. Silicon- mediated changes on some physiological and enzymatic parameters symptomatic of oxidative stress in barley grown in sodic-B toxic soil. Journal of Plant Physiology, v. 164, n. 6, p. 807-811, 2007 a.

GUNES, A. et al. Influence of silicon on antioxidant mechanisms and lipid peroxidation in chickpea (Cicer arietinum L.) cultivars under drought stress. Journal of Plant Interaction, v. 2, n. 2, p. 105-113, 2007b.

GUNES, A. et al. Influence of silicon on sunflower cultivars under drought stress. I: Growth, antioxidant mechanisms, 
and lipid peroxidation. Communication in Soil Science and Plant Analysis, v. 39, n. 1, p. 1885-1903, 2008.

HEINEMANN, A. B; STONE, L. F.; FAGERIA, N. K. Transpiration rate response to water deficit during vegetative and reproductive phases of upland rice cultivars. Scientia Agricola, v. 68, n. 1, p. 24-30, 2011.

KAO, C. H. Differential effect of sorbitol and polyethylene glycol on antioxidant enzymes in rice leaves. Plant Growth Regulation, v. 39, n. 1, p. 83-89, 2003.

LIANG, Y. Effects of silicon on enzyme activity and sodium, potassium and calcium concentration in barley under salt stress. Plant and Soil, v. 209, n. 2, p. 217-224, 1999.

LIMA, M. D. S. et. al. Effect of salt stress on pigments and proline concentrations in leaves of rice. Bragantia, v. 63, n. 3, p. 335-340, 2004.

MA, J. F. et al. Silicon transporter in rice. Nature, v. 440, n. 7084, p. $688-691,2006$.

MA, J. F. Role of silicon in enhancing the resistance of plants to biotic and abiotic stresses. Soil Science and Plant Nutrition, v. 50, n. 1, p. 11-18, 2004.

MACIEL, H. P. F. et al. Extraction, purification and biochemical characterization of a peroxidase from Copaifera langsdorffii leaves. Quimica Nova, v. 30, n. 5, p. 1067-1071, 2007.

MING, D. F. et al. Effects of silicon on the physiological and biochemical characteristics of roots of rice seedlings under water stress. China Agriculture Science, v. 45, n. 12, p. 2510-2519, 2012.

NASCENTE, A. S. et al. Cover crops and no-till effects on physical fractions of soil organic matter. Soil and Tillage Research, v. 130, p. 52-57, 2013.
QU, Y. et al. Mapping QTLs of root morphological traits at different growth stages in rice. Genetica, v. 133, n. 2, p. 187200, 2008.

RAIJ, B. V. et al. Análise química para avaliação da fertilidade de solos tropicais. Campinas: Instituto Agronômico, 2001. 284 p.

RAYMOND, M. J.; SMIRNOFF, N. Proline metabolism and transport in maize seedlings at low water potential. Annals of Botany, v. 89, n. 7, p. 813-823, 2002.

RICHARDS, L. A. Methods of measuring moisture tension. Soil Science, v. 68, n. 1, p. 95-112, 1949.

SHARMA, P.; DUBEY, R. S. Modulation of nitrate reductase activity in rice seedlings under aluminium toxicity and water stress: role of osmolytes as enzyme protectant. Journal of Plant Physiology, v. 162, n. 8, p. 854-862, 2005.

TORELLO, W. A.; RICE, L. A. Effect of $\mathrm{NaCl}$ stress and proline and cation accumulation in salt sensitive and tolerant turfgrasses. Plant and Soil, v. 93, n. 2, p. 241-247, 1986.

VERMA, S.; DUBEY, R. S. Lead toxicity lipid peroxidation and alters the activities of antioxidant enzymes in growing rice plants. Plant Science, v. 164, n. 4, p. 645-655, 2003.

WANG, S. Y.; GALlETTA, G. J. Foliar application of potassium silicate induces metabolic changes ins strawberry plants. Journal of Plant Nutrition, v. 21, n. 1, p. 157-167, 1998.

ZHU, Z. et al. Silicon alleviates salt stress and increases antioxidant enzymes activity in leaves of salt-stressed cucumber (Cucumis sativus L.). Plant Science, v. 167, n. 2, p. 527-533, 2004. 